\title{
Editorials
}

\section{Video comes to the Journal}

Andrew S. Wechsler, MD

Pamela W. Fried

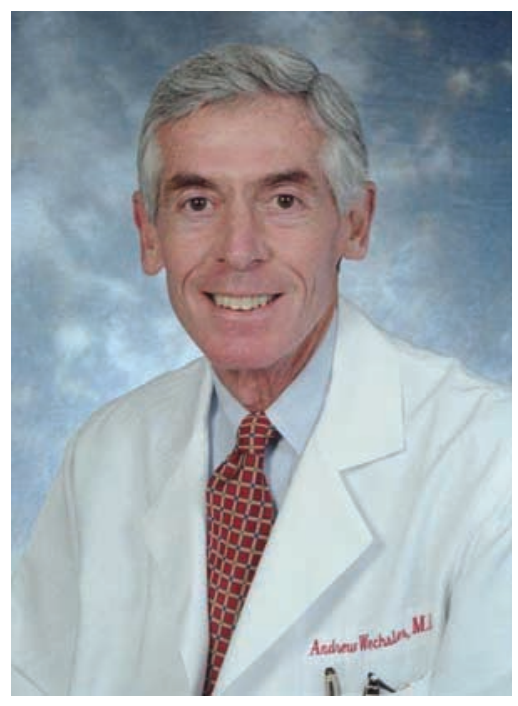

Dr Wechsler

See related article on page 863 .
From Drexel University College of Medicine, Philadelphia, Pa.

Received for publication Aug 8, 2002; accepted for publication Aug 16, 2002.

Address for reprints: Pamela W. Fried, 245 North 15th St, MS 496, Philadelphia, PA 19102-1192.

J Thorac Cardiovasc Surg 2002;124:884-5

Copyright $\odot 2002$ by The American Association for Thoracic Surgery

$0022-5223 / 2002 \$ 35.00+0 \quad \mathbf{1 2 / 1 / 1 2 9 1 3 8}$

doi: $10.1067 / \mathrm{mtc} .2002 .129138$

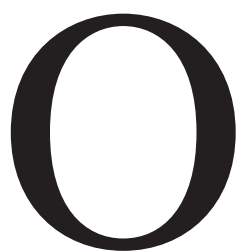

ur specialty is interesting because it attracts, at one extreme, some individuals who enjoy the purely technical aspects of thoracic surgery and, at the other, those who enjoy the predominantly analytic aspects of thoracic surgery. Most of us, of course, fall somewhere in the middle, with a balanced interest in both areas. We enjoy the work we do in the operating room-the creative opportunity it provides, the reward that comes with good craftsmanship. To do what is best for our patients, however, we must be informed and constantly reevaluate results through complex outcome analyses. The Journal devotes substantial space to precise characterizations of the consequences of technical advances and approaches to patient disease. Techniques are useful only if they provide a beneficial outcome.

We review many articles that focus heavily on outcome analysis based on the application of complex techniques. We present the outcome data through careful use of statistical principles, visual aids such as tables and graphs, and critical discussion of the interpretation of the data. However, we have not fulfilled our mission if the author's description of the procedure he or she is using is not absolutely clear and if the words of the author do not mean the same thing to all readers. Examples include describing aortic annular reduction as taking smaller bites in the external Teflon support than in the stitches taken through the anulus or removing a "small" amount of lung tissue using a videoscopic technique when resecting pulmonary nodules. Positioning an incision "below the right breast" leaves a lot to the imagination. Constructing a baffle for complex diversion of blood flow in congenital heart disease is one matter when presented with an illustration of the "baffle" and quite another when it comes to actually sewing it in place. Yet, outcome analyses are based heavily on the extent to which the author's technique is consistently applied.

To facilitate this process, it is now possible for authors to provide a brief video showing exactly the critical components of the technique that they have used in their articles. Our first article with a video component is the article by Gerald Buckberg on page 863 of this issue. You may view the video segments and additional illustrations not included in the print article by accessing the Journal on line via CTSNet (http://jtcs.ctsnetjournals.org/) or via Elsevier Science (www.mosby.com/ jtcvs). Dr Buckberg's basic science presentation at the Eighty-first Annual Meeting of The American Association for Thoracic Surgery in San Diego relied heavily on complex visual representations difficult to describe in words. The unwinding of the single muscle band that forms the heart, helical structures in the heart and nature, and movements understood best by illustration. The opportunity to view some of this original material should be pleasant and enlightening.

Videos you submit may not be more than 1 minute long and no more than $5 \mathrm{MB}$ in file size. They are not intended to be a substitute for on-site learning, for full video 
technique presentations, or for competing with "How I do it" journal formats. These videos are rather intended as a visual supplement to scientific articles to further clarify the article for our readers. We wish to emphasize that articles must be entirely complete without the video component and that the video component is a visual "add-on" but not a substitute for clarity within the methods section. Access to the videos will be limited to subscribers to the Journal.

Video files must be submitted to the editorial office, accompanied by a separate copyright transfer form. At this point, they cannot be submitted via Editorial Manager. The Editor must approve all videos. Specific instructions for video preparation are available at http:// www.harcourthealth.com/scripts/om.dll/serve?web=videoall.html. Please adhere to these requirements. The Journal does not provide studio production work. General instructions for video submission will be included in the Instructions to Authors in the Journal and on line.

\section{JTCVS On-Line Manuscript Submission and Review}

\section{Please visit http://www.editorialmanager.com/jtcvs/}

Effective September 15, 2001, authors and reviewers may submit manuscripts and reviews electronically via Editorial Manager, our new Web-based system with full electronic submission, review, and status update capabilities.

As we move from paper to electronic submissions, the Editorial Office will make proxy submissions of all manuscripts accompanied by a diskette containing the electronic files of the text, tables, and figures. Editors, authors, and reviewers will receive automatic e-mails when significant events occur.

We strongly encourage all authors and reviewers to use Editorial Manager. Although we will continue to accommodate the submission of paper manuscripts for some months, our goal is to be completely electronic within 9 to 12 months.

All individuals currently in our database for whom we have e-mail addresses will receive via e-mail a system-assigned username and password that can be used to log in to the system without prior registration. All those not receiving the e-mail must register the first time they use the system.

As with any broad systemic change, the conversion to the new system will take some time to complete. We ask your patience as we replace our in-office database with the new system. We also encourage you to take advantage of the speed and efficiency that the new system will provide for us all: editor, author, reviewer, and publisher. 